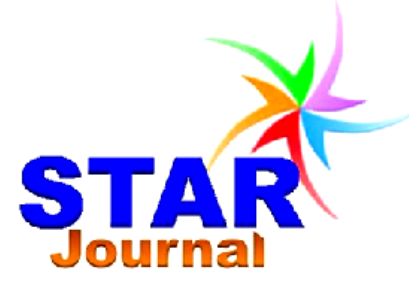

ISSN: 2226-7522(Print) and 2305-3327 (Online) Science, Technology and Arts Research Journal April-June 2012, 1(2):76-80 www.starjournal.org Copyright@2012 STAR. All Rights Reserved

Original Research

\title{
Early History of Written Oromo Language up to 1900
}

\author{
Tesfaye Tolessa \\ Department of History and Heritage Management, College of social sciences, Wollega University, \\ Post Box No: 395, Nekemte, Ethiopia
}

\begin{tabular}{|c|c|}
\hline Abstract & Article Information \\
\hline \multirow{11}{*}{$\begin{array}{l}\text { The purpose of this paper is to make known historical development of written } \\
\text { Afaan Oromo to } 1900 \text {. The study draws upon primary and secondary sources. } \\
\text { The primary data are drawn from oral and archival sources. Books and articles } \\
\text { in Afaan Oromo and in other languages about Afaan Oromo were consulted. } \\
\text { Many of these sources are not only indicators of the status of written Oromo but } \\
\text { also of situations that the Oromo people have endured over decades and } \\
\text { centuries. The paper reveals how the assimilation activity targets above all the } \\
\text { language of the society to be assimilated and how Afaan Oromo had been able } \\
\text { to survive such assimilation policy of successive Ethiopian regimes. In addition, } \\
\text { it puts an overview on how the missionaries, foreign travelers, religious } \\
\text { personalities and some Ethiopians attempted to reduce Afaan Oromo into } \\
\text { written language. It gives an idea about the beginning of writing Afaan Oromo in } \\
\text { the early } 17^{\text {th }} \text { century. The study also indicates the school founded in those } \\
\text { problematic periods to teach in Afaan Oromo and the translations of many } \\
\text { books into Afaan Oromo. }\end{array}$} & Article History: \\
\hline & Received : 14-02-2012 \\
\hline & Revised : 18-06-2012 \\
\hline & Accepted : 20-06-2012 \\
\hline & Keywords: \\
\hline & \\
\hline & Scripture \\
\hline & $\begin{array}{l}\text { Abbaa massaja } \\
\text { Written oromo literature }\end{array}$ \\
\hline & *Corresponding Author \\
\hline & Tesfaye Tolessa \\
\hline & E-mail: tesfayetol2008@yahoo.com \\
\hline
\end{tabular}

\section{INTRODUCTION}

Literature is linguistically documented facts and ideas through which people used to preserve their deeds and worldviews from one generation to the other (Owamoyala, 1993). It is also important to note that one cannot separate language and culture from literature that define them. Language is therefore, a pedestal in the evolution of literature as it is one of the typical ingredients in one's awareness of her/his culture, identity, custom and history. The sources to study the historical movements of human beings have come from the study of languages that were spoken by the preceding generations as a proto language. This is because, language harbors human culture, knowledge, arts, history and others (Isichei, 1995; Yule, 1996; Ehret, 2008). This is also true for Oromo language what the Oromo prefer to call Afaan Oromo (henceforth Afaan Oromo).

Among the Cushitic language families to which it belongs, Afaan Oromo ranks first by the number of its speakers. It is the third among the widely spoken languages in Africa next to Swahili and Hausa Languages. It is a common language among many nationalities, like the Harare, Bartha, Shinahsa, Anuak, Sidama, Gurage (Mekuria, 1994), Koma, Yam, Kaficho, Dawuro, Gedeo, Konso, Somali, Afar, Amhara, and others (Feyisa, 1996). The indigenous speakers are uninterruptedly distributed from Southern Tigray in the North to Northern Kenya in the South, and from Harar in the East to Gidaamii in the West (Gada, 1998; Richard, 1995; Baxter, 1978). They form the largest homogenous culture sharing common descent, history and psychological makeup (Baxter, 1978). Geographically, except in the Northern, Afaan Oromo is found in Eastern, Southern, Central and Western Cushitic Language families by retaining its homogeneity. The Oromo of all these areas could communicate in this language without dialectical barriers (Ibid.). Despite these facts, it is denied official status and no comprehensive scholarly study conducted on it. 


\section{Some Facts as a Precursor to Written Oromo Language}

Recent sources are reveal the neglected history of Afaan Oromo under its past consecutive Ethiopian rulers. The attempts of the rulers to lock up Afaan Oromo's outlets where they had been are now being wearied away by discovering of the sources which were masked by the scholars of Ethiopian history under the influences of her rulers. Jackson who made anthropological and historical studies of the civilizations of the Middle East and Northeast African states that Afaan Oromo is the purest living specimen of primitive Babylonian languages. $\mathrm{He}$ asserts that when the other languages have since been mixed up with other languages, Afaan Oromo in Ethiopia and Mahra in South Arabia have been able to maintain their purity without significant changes. As he put it:

In regard to the language of the primitive Babylonians, the vocabulary is undoubtedly Cushite (Cush Ethiopia), belong to that of tongue which in the sequel were everywhere more or less mixed up with the Semetic languages, but of which we have probably the purest modern specimens is the Mahra of South Arabia and the [Oromo] of Ethiopia (John G. Jackson, 1974)

Šihãb ad Din Ahmad bin Abd al-Qãder, Chronicler of Imam Ahmad bin Ibrahm al-Gahz and an Arab writer, indicates that the Yejjuu Oromo had been well established in Walloo before the war of Imam Ahmad bin Ibrahim alGahz. According to Šihãb ad Din, the Imam ordered his soldiers to speak only Yejjuu (Oromo) language as the area was populated by the Yejjuu Oromo. Even, the Imam recruited more than three thousand Yejjuu Oromo into his soldiers (Lester Stenhouse, 2003). This indicates that Afaan Oromo was a popular language in northern Ethiopia before the alleged Oromo expansion of the sixteenth century began.

Similarly, Abbaa Bahrey (1993) who is said to have been the author of "Zenaw Lahula (Oromo)" written in 1593 employed many Oromo names and terminologies like gadaa, malbaa, muudana, Tuulama, Maccaa, Galaan, walaabuu and many cultural concepts. Moreover, the book leads us to raise an argument that there was at least one person who knew both Geez and Oromo languages to have produced the book. Otherwise, as Jan Vansina (1995) states it is difficult for someone to collect oral tradition of the society whose language he/ she did not know. At the very least, it would have been impossible to get oral information embodied in the book without Abbaa Bahrey's using the services of Oromo with good knowledge of the Geez language. Whether Abbaa Bahrey knew Oromo or used the services of others, the literature of the book written by him is another instance of an indirect entrance of Oromo into written literature.

\section{Early Printed Sources of Written Oromo Language}

In the middle of seventeen century, Hiob Ludolf, in his linguistic production, wrote a few Oromo words with its parallel translation in Geez and Latin. According to Ludolf (1682), the Oromo words were told to him by Abbaa Gregory between 1652 and 1658 which again gives clue that Abbaa Gregory was well versed in Oromo language. This book in which Oromo words were written appeared in 1682. It is the first written words of the Oromo language we have at our disposal. James Bruce, who visited Ethiopia, did some work related to Afaan Oromo. (Jumce Bruce, No year of publication) In his journey to discover the Source of Blue Nile, Bruce had the opportunity to be among the Oromo of Walloo. Bruce was the first traveler and second European writer next to Hiob Ludolf to record the Oromo language in his account as one of the major languages he had come across. According to his report, he had wished to get ready made written literature for the languages; but he points out that he could not get even one because of the traditional law that forbade the translation of any religious documents into any language other than Geez (Ibid.). The act was religiously condemned and became immoral. As he puts it:

\footnotetext{
...there is an old law in this country (Ethiopia), handed down by tradition only, that whoever should attempt to translate the holy scripture into Amharic, or any other language, his throat should be cut after the manner in which they kill sheep, his family sold to slavery, and his house razed to ground...it was great obstacle to me in getting those translations of the song of Solomon made which I intended for specimens of different language of those distinct relations (Ibid.).
} 
Daringly breaking that traditional law, he translated Solomon's alleged praise for the Queen of Sheba into Afaan Oromo by using Geez characters on a page of his work. This is the second early tangible evidence of the beginning of writing in Afaan Oromo.

Afaan Oromo was a palace language during the reign of lyoas who was monolingual in Afaan Oromo (Richard Greenfield, 1965). The employment of 3,000 soldiers as palace guards (Tesfaye Zergaw, 2001; Trimngham, John, 1965) helped to make Afaan Oromo virtually the official language of the palace (Martial De Slavic, 2008). The occupation of the position of Ras Bitwedid by the Yeijuu lords from the middle of 1770 onwards (Ibid.). Further exalted the use of Oromo language in the state system. On the other hand, many Oromos who were sold into slavery attempted to make Afaan Oromo popular under the opportunities got to be Christian preachers (Ibid.). Although the origin of Alaqa Zannab, Chronicler of emperor Tewodros, there were many freed Oromo slaves participated in the translation of the scripture before the popular Abba Gammachis (Onesmos Nasib), Zannab , Ruufoo, Waaree, Jagaa, Soolaan and Liban (Wolbert Smidt, 2002) are few among many.

The translation of the Scriptures into Oromo language continued. On June 30, 1877, Menilek ordered Alaqa Zannab to translate the books of Jeshewa, Judge Ruth, and Samuel to use the translation for himself for revision after Hebrew. However, the works did not see light of the day due to the death of Krapf, who used to publish Alaqa Zannab's works, in 1881 and the unstable political situation between the interior and the coast. Nevertheless, R. Pankhurst, who has written about these materials, does not explain why Menilek II preferred Afaan Oromo to Amharic for the revision of the Hebrew Bible (Pankhurst, 1976). But the reason is clearly stated by Hudeson "It is a curious fact that, although so many of the great Abyssinian officers are pure [Oromo], and although nearly every Abyssinian know[s] [Oromo] as well as Amharic, yet they do not care to speak [Oromo] in public. This can only be ascribed to a kind of false pride, as in private they will talk it readily" (Hudeson and Walker, 1922).

To have indigenous religious scholars who could study Oromo language scientifically and translate the religious scripture into the language, the Catholic missionaries invested lots of their efforts on Afaan Oromo. Abbaa Massaja intensively continued to request the opening of (Oromo) College in France. It was great for
Massaja to get land for the construction of (Oromo) College on 18 January 1866 in Marseille. On $15^{\text {th }}$ April, 1866, St. Michael Oromo College was officially inaugurated by Massaja Marseille, France. By February 1869, the college was reported to have enrolled about twenty-nine Oromo students collected especially from ransom slaves (Abba Antonios Alberto, 1998).

For the first three years, the Oromo College was functional to teach theology and linguistics with the focus on Oromo language under the direction of Fr. Emanuel and Louis de Gonzangue Lassere. However, it was unfortunate that the Oromo students of the College could not acclimatize well with the weather and many of them died (Ibid.). This forced Massaja to try to establish another College in the homeland of the students in order to fulfill the pastoral missions of the vicariate. Following his requests, the Capuchin of propaganda Fide allowed Massaja to build another (Oromo) College in the Oromo country in 1868. As soon as he received the letter of permission, Massaja left for Shawaa accompanied by his four Marseille Oromo students and instructors. After forty-eight days of tiresome journey, they reached Liche, the king's court at the time on March 11, 1868 (Ibid.). Based on Menilek's advice Massaja sent Fr. Tuarin, the vice-perfect of the mission to Finfinnee with some of the Oromo students on 11 September 1868. Immediately they began constructing Catholic Church of St. Marry at Birbirsaa with the assistance of some Oromo people (Ibid.). Birbirsaa (Oromo) College was officially inaugurated on 25 July 1869. The former instructor of the Marseille Oromo College, Fr. Emanuel and Fr. Louis de' Gonzague were sent to teach at the college but Fr. Emanuel died on the way to Shawa. Louis de' Gonzague became the director of (Oromo) college of Birbirsaa in 1873 (Ibid.). At this College, Fr. Tuarin prepared religious texts in Oromo language for church and academic services. Attempts were made to produce religious and academic literature both in Oromo language (Ibid.). At the college, many recruits and some freed Oromo slaves, enrolled and became literate. The trained Oromo also participated in productions and translations of Oromo language literature as both writers and assistants to the foreigners.

Nonetheless, the progress of Catholic Missionaries' expansion and its roles in the development of written Oromo literature were impeded by Emperor Yohannes's suspicious policy of king Menilek's secrete contact with the Europeans. Yohannes feared that Menilek might have earned ample firearms through the contact. 
Consequently, Yohannes ordered Menilek to stop contacting Europeans independently and the two sealed this in one of the articles of the Liche Agreement signed in 1878. The agreement forced Menilek to expel Europeans including all the Catholic missionaries from Shawaa. (Elio Ficquet, 2003) After thirty years of evangelical activity and Oromo language study in Ethiopia, Massaja was expelled (Tewelde Beyene, 2003). The mission station and the (Oromo) College of Birbirsaa had to close down. In 1897, the St. George Church was built on the site of the college by the order of Menilek (Alberto, 1998).

Despite these challenges and obstacles, the catholic missionaries had never given up their mission of evangelizing the Oromo and translating books into Oromo language. Mgr. Cahagne, who became Vicariate Apostolic of the Oromo following the resignation of Massaja on 3 October 1879, designed another way to enter the Oromo land. Mgr. Cahagne and his compatriots were able to pass through Zeila and established themselves at Harar in 1881. In Harar, they established two schools; one for freed slaves and the other for missionaries. In both schools Afaan Oromo and Arabic languages were intensively given. Fr. Andre Jarosseau was busy in studying Afaan Oromo and Arabic in Harar during 18821883, which could be a key for his future apostolate among the Oromo. (Kevin, O'Mahone, and Wolbert Smidt, 2003).

Parallel with the establishment Oromo College and missionary station, the Catholic Missionaries embarked on collecting Oromo words, studying its grammar. They also translated their religious scriptures into Oromo language. In addition to the 1853 of catechism translation, Abbaa Jacob had translated the gospel of Matthew into Oromo language. He published the book which was 135 pages long at the printing house of Banasfus in Carcassonne in 1900. The main constituent of the translation is 28 chapters of Matthew, Morning and Evening Prayers, Revelation of Sin, and the Ten Commandments. Like his translation of 1853, the book has the problem of precise representation of Oromo sounds which is difficult only for the non-native learners but also for the natives themselves. His orthographical usage is based on the accent of French language. Otherwise, Jacobi had the concept of Oromo words that are long or stressed (Abba Antonios Alberto, 1998).

The attempt of translating and composing Oromo language continued. In 1887, Ettore
Viterbo an Italian scholar published Afaan Oromo grammar in Italian language under the title Grammatica Della Lingua Oromonica in Ermanno. The grammar consists of about 397 pages majority of which is devoted to the discussion in Italian language. The first hundred pages are devoted to Oromo grammar, from 103266 to Oromo-Italian and from 267-397 to ItalianOromo vocabularies where as the rest is left for Kaficho, Yem and the other Southern nations' grammar. In the book Oromo words, phrases and sentences written in Latin script are cited as an example under each explanation of the grammar with it transcriptions into Italy. As he states in his grammar, his Oromo-Italian and Italian-Oromo bilingual vocabularies were aimed at easing twoway translations that was to benefit both the Oromo and Italian speakers. (Abune Jacobi, 1900) Nonetheless, as his approach of both the grammar and the vocabularies orthographic representation of Oromo sounds are the corruptions of Italian sounding system that it is difficult to pronounce Oromo words correctly for both the Oromo and nonnatives. Similarly, Franz Praetorius a German scholar, published Zur Grammaticka der Gallasparche in 1893 in Berlin. Praetorius' 130 pages of Oromo grammar in Germany employed Geez script for the Oromo words, phrases and sentences cited in the book to show the practicality of the discussion. (Franz Praetorius, 1993) In this grammar, the focus he made on Oromo language is not worth as most part of the account is left for the German.

\section{CONCLUSIONS}

Although Oromo nation has been one of the largest ethno nations in Ethiopia, the attention given to study their language particularly from historical aspect is remains minimal. Policy of marginalization was also exercised for the purpose of building a country of one language, religion and culture. Promotion for the language was inspected and strictly forbidden. Therefore, the Oromo language in general and written Oromo literature in particular remained less studied. Until recently, Afaan Oromo lacked developed written literature and has insignificant written and printed materials. In spite of this pressures, some literate Ethiopians, foreigners, religious men and sold Oromo slaves to Europe tried to document some sketches of Afaan Oromo whenever they got any opportunity they came across. These efforts enabled us to take down the origin of written Oromo literature down to $17^{\text {th }}$ century. 


\section{REFERENCES}

Alberto Abba Antonios. (1998). Ethiopian Review of Cultures: The Apostolic Vicariate of Galla, A capuchin Mission in Ethiopia (1846-1942): Antecedents, Evolution and Problematic. Ph.D Dissertation in Philosophy and Theology.

Bahrey. (1993). History of the [Oromo] of Ethiopia with Ethnology and History of South west Ethiopia.Oakland: African Sun Publishing.

Bahru Zewde. (2002). A History of Modern Ethiopia, 1855-1991, Second edition. Oxford, James Carrey, Athens: Ohio University Press, Addis Ababa, Addis Ababa University.

Bairu Tafla. (1981). Ethiopia and Germany: Cultural, Political and Economic Relation, 1871-1936. Wiesbaden: Franz Steiner.

Baxter John. (1978). Ethiopia's Unacknowledged Problem of the Oromo in African affairs. Journal of the Royal Society 77(308): 287-299.

Bruce, J. Travels to Discover the Source of the Nile in the Years 1768, 769, 1770, 1771, 772 and 1773, V.I. Edinburg: Jruthuen.

De Slavic Martial. (2008). The Oromo: An Ancient People Great African Nation by $\left(2^{\text {nd }}\right.$ ed.) Translated by Ayalew Keno .Finfinnee: Oromiya Cultural and Tourism Bureau,

Ehret Christopher. (2000). Language and History in Bernd Heine and Derk Nurse (Eds.) African Languages: An Introduction. Cambridge University Press, Cambridge.

Feyisa Demie. (19960). Historical Challenges in the Development of Oromo Language and Some Agenda for Future Research. Journal of Oromo Studies 3(1\&2): 18-27.

Ficquet Elio. (2003). Cahagne Tuarin. In: Encyclopedia Aethiopica, V.1. Harrassowitz Verlag, Wiesbaden.

Greenfield Richard. (1965). Ethiopia: A New Political History. Pall Mall Press, London.

Gustave Arén (1978). Evangelical Pioneers in Ethiopia: The Origin of Evangelical Church Mekane Yesus. Uppsala University, Stockholm.

Hudeson., Arnauld., Charven Walker. (1922). An Elementary and Practical Grammar of the Galla for Oromo Language. William Claws and Sons LMT, London.

Hyward Richard. (2000). Afro-Asiatic in Bernd Heine and Derek Nurse Eds. African Languages: An Introduction. Cambridge University Press, Cambridge..

Isichei Elizabeth. (1995). A History of Christianity in Africa: From Antiquity to the Present. African World Press, Lawrenceville, New Jersey.

Jacobi Abune. (1900). Wangelium Nagaa: Qedus Mateos Akka Kitabe. Karkasone: Mana Bonnafus.
Jackson G. John. (1974). Ethiopia and the Origin of Civilization. Black Classic Press, Baltimore.

Ludolf, Job. (1982). A new history of Ethiopia. Sasor Publisher, London.

Mekuria Bulcha. (1994). The Language policy of Ethiopian Regimes and the History of Written Afaan Oromo: 1884-1994. The Journal of Oromo Studies 1(2): 91-115.

O'Mahoney Kevin., Wolbert Smidt. (2003). "Finfinnee" In: Encyclopedia Aethiopica, Volume 2. Wiesbaden: Harrassowitz Verlag, pp: 545-546.

Owamoyala Oyekan. (1993). The Question of Language in African Literature. A History of Twentieth Century African Literature (ed.). University of Nebraska press, Oyekan Owamoyala, Lincoln and London.

Pankhurst, R. (1976). The Beginning of Oromo Studies in Europe. In: Africa Rivista Trimestraledi Studie Documentizione Dell' Instituto Africano 31(2): 11-17.

Praetorius Franz. (1893). Zur Grammatik Der Galla Sparche. Verlag Von Reuther and Reichard, Berlin.

Smidt, Wolbert. (2002). The Unknown First Oromo Bible Translator Christian Rufo: Some Insight From Private Missionary Achieves. In: Baye Yimam (eds.) Proceedings of Fourteenth International Conference of Ethiopian Studies, Volume 1. Addis Ababa, Institute of Ethiopian Studies, pp. 634-663.

Stenhouse Lester. (2003). The Conquest of Abyssinia by Šihãb ad Din Ahmad bin Abd al-Qãder. Tsehay Publishers and Distributors, Addis Ababa.

Tesfaye Zergaw. (2001). A Survey of World, Africa and Ethiopia. Mega Publishing enterprise, Addis Ababa.

Teshome Wagaw (1979). Education in Ethiopia: Prospect and Retrospect. The University of Michigan Press, Ann Arbour.

Tewelde Beyene. (2003). Massaja, Guglielm. In: Encyclopedia Aethiopica, Volume 3. Wiesbaden: Harrassowitz Verlag, pp: 848-849.

Trimngham,S. John. (1965). Islam in Ethiopia. Cambridge University Press, London.

Vansina, Jan. (1965). Oral Traditions: A Study in Historical Methodology. Harmonds worth, Penguim Books Ltd.

Viterbo, E. (1892). Grammaticae Dizionaric Della Lin gua Oromonica, Vocabularic Della Lingua Oromonica Compilato Sulle Noteed Appunti Delling. Milano: Gichiaarini Del Missionaric P. Leon Des Aventurres.

Yule George.(1996). The Study of Language ( $\left.2^{\text {nd }} e d\right)$. Cambridge University Press, Cambridge.

Zimz Petr. (1976). Introduction in Black Africa: Literature and Language by Valdimir Kalima, Karel František Růžžěčka and Petr Zima. Holand, D Reidel Publishing Company, pp: 30-51. 